\title{
Heat Tolerance in Lentil under Field Conditions
}

Kumar J. ${ }^{1,}$, Kant R. ${ }^{1}$, Kumar S. ${ }^{2}$, Basu P.S. ${ }^{3}$, Sarker A. ${ }^{4}$, Singh N.P. ${ }^{1}$

1 Division of Crop Improvement, ICAR-Indian Institute of Pulses Research, Kalyanpur, Kanpur-208024, India

2 Biodiversity and Integrated Gene Management Program, International Centre for Agricultural Research in the Dry Areas (ICARDA), P.O. Box 6299,

Rabat-Institute, Rabat, Morocco

3 Division of Basic Sciences, ICAR-Indian Institute of Pulses Research, Kalyanpur, Kanpur-208024, India

4 ICARDA South Asia \& China Regional Program, NASC Complex, DPS Marg, New Delhi-110012, India

B Corresponding author Email: jitendra73@gmail.com

Legume Genomics and Genetics, 2016, Vol.7, No.1 doi: 10.5376/lgg.2016.07.0001

Received: 23 Nov., 2015

Accepted: 05 Jan., 2016

Published: 23 Mar., 2016

Copyright $\odot 2016$ Kumar et al., This is an open access article published under the terms of the Creative Commons Attribution License, which permits unrestricted use, distribution, and reproduction in any medium, provided the original work is properly cited.

Preferred citation for this article:

Kumar J., Kant R., Kumar S., Basu P.S., Sarker A., and Singh N.P., 2016, Heat tolerance in lentil under field conditions, Legume Genomics and Genetics, 7(1): 1-11 (doi: 10.5376/lgg.2016.07.0001)

\begin{abstract}
In the present study, 334 lentil accessions were screened for heat tolerance under field conditions in 2011-12 and 160 accessions encounter high temperature $\left(>35^{\circ} \mathrm{C}\right)$ during the reproductive stage were again screened in 2012-13. Only 37 accessions podded normally and showed pod formation on terminal branch were identified heat tolerant and remaining 59 accessions podded rarely but flowered were identified sensitive to higher temperature. The combined analysis of variance over the years indicated significant genotypic variability for filled and unfilled pods/plant, filled pods on terminal branch and also for 100-seed weight. High heritability was estimated for filled pods/plant (46.3\%) and filled pods on terminal branch (58.1\%). Based on maximum number of filled pods per plant and on terminal branch along with lower standard error of mean over the years resulted in identification of heat tolerant genotypes (FLIP2009-55L, IG2507 and IG4258). These genotypes also showed higher pollen viability at higher temperature, indicating the usefulness of above trait for identification of heat tolerant donors for lentil breeding program.
\end{abstract}

Keywords Filled and unfilled pods; 100-Seed weight; Pollen viability; High temperature; Lentil

\section{Introduction}

Lentil (Lens culinaris subsp. culinaris Medikus) is an important cool-season legume crop of rainfed agriculture for diversification and intensification of cereal-based cropping systems worldwide. It is grown globally on 3.74 mha area and produces $3.40 \mathrm{mt}$ of grains with an average productivity of $915 \mathrm{~kg} \mathrm{ha}^{-1}$ (Erskine et al., 2011). India shares about 0.94-1.03 mt (28\%) of global lentil production by cultivating it on 1.48-1.59 mha area. It is mostly grown under residual soil moisture conditions during the winter season and hence this crop invariably encounters drought and heat stresses at the time of podding and grain filling period when temperature rises suddenly. As a result it leads to forced maturity and lower yield. In recent years, the global warming has become as a major challenge to rainfed agriculture. It has predicted that heat stress will have more adverse effects on vulnerability of food crops under climate change rather than drought. Therefore, in coming years, high temperature can be an important constraint in lentil production, if night temperature rises by at least $2{ }^{\circ} \mathrm{C}$. Due to this in India, northern part can have higher levels of warming by 2050, while its central and north-eastern parts now have about 11.7 mha as fallow after late harvest of rice and delayed sowing of lentil in these areas encounters force maturity due to high temperature (Subbarao et al., 2001).

In lentil, flowering is known to be very sensitive to changes in external environment especially in temperature and photoperiod. Therefore, heat stress at reproductive stage causes heavy loss in grain yield of lentil (Summerfield et al., 1985). Thus, heat tolerant cultivars can provide not only an opportunity of horizontal expansion of lentil cultivation in rice-fallow lands but also can help to increase lentil productivity by minimizing the yield losses occurring due to forced maturity. It can be visualized that the increases in temperature will have more adverse effects on cool-season crops (e.g. lentil) than the rainy-season crops (Kumar, 2006). Therefore, identification of heat tolerant genotypes in available germplasm and their 
utilization can help to tackle situation of terminal heat stress through the development of heat tolerant cultivars. Earlier, efforts have been made in other cool-season legume like chickpea to identify the heat tolerant genotypes under field conditions (Dua, 2001; Krishnamurthy et al., 2011).

Yet, it is still not clear how heat affects the growth and development of lentil and whether that can explain part of the differences in seed yield under heat stress. Therefore, it is an urgent need to identify the traits that can be used effectively in field conditions for screening germplasm and breeding materials at reproductive stage. Keeping this in view, the present study aimed (i) to establish an effective screening technique under the field condition by identifying the morphological traits related to heat tolerance and yield and (ii) to validate identified heat tolerant genotypes using laboratory test.

\section{Results}

\subsection{Genetic variability}

The procedure used to screen the heat tolerant genotypes is presented in Figure 1. In the present study, out of 334 accessions, 174 accessions flowered early and matured within 80-85 days after sowing. These accessions escaped the heat stress and thus were excluded for further analysis. Another 64 accessions which did not flower or flowered rarely were considered as highly sensitive to heat. The remaining 96 accessions whose flowering and podding stage coincided with high temperature and still flowered were observed for the number of filled pods/plant, number of unfilled pods/plant, and number of filled and unfilled pods on terminal branch of individual plants. These accessions flowered in 56 to 85 days (between March 15 and April 30, 2012) when the maximum day temperature varied between 30.6 and 43 ${ }^{\circ} \mathrm{C}$ (Figure 2). As a result, development of pods at maximum day temperature $\left(>35^{\circ} \mathrm{C}\right)$ was used as a criterion to classify accessions as tolerant or sensitive to heat. Thirty seven (37) accessions, which podded normally and showed pod formation on terminal branch, were classified as heat tolerant while remaining 59 accessions that flowered but podded rarely were classified as sensitive to higher temperature. The mean, range and standard error of mean (s.e.m) over two years of these 37 accessions were calculated, which is presented in Table 1 .
Among 37 accessions, number of filled pods/plant ranged from 3.3 to 51.2 with an average of 23.6 while unfilled pods ranged from 5.5 to 45.0 with an average of 24.2. On terminal branch, filled pods were varied from 1.5 to 10.0 with an average of 3.3 and unfilled pods were varied from 0.0 to 3.8 with an average of 1.3. The 100-seed weight in these 37 accessions ranged from 1.1 to $2.5 \mathrm{~g}$ with an average of $1.3 \mathrm{~g}$. The combined analysis of variance over the years indicated significant genotypic variability for filled and unfilled pods/plant, filled pods on terminal branch and also for 100-seed weight (100-SW). Heritability estimates ranged from 8.94 to $58.13 \%$ (Table 2). Highest heritability $(58.13 \%)$ was observed for filled pods/plant on terminal branch and it was lowest $(8.94 \%)$ for unfilled pods/plant.

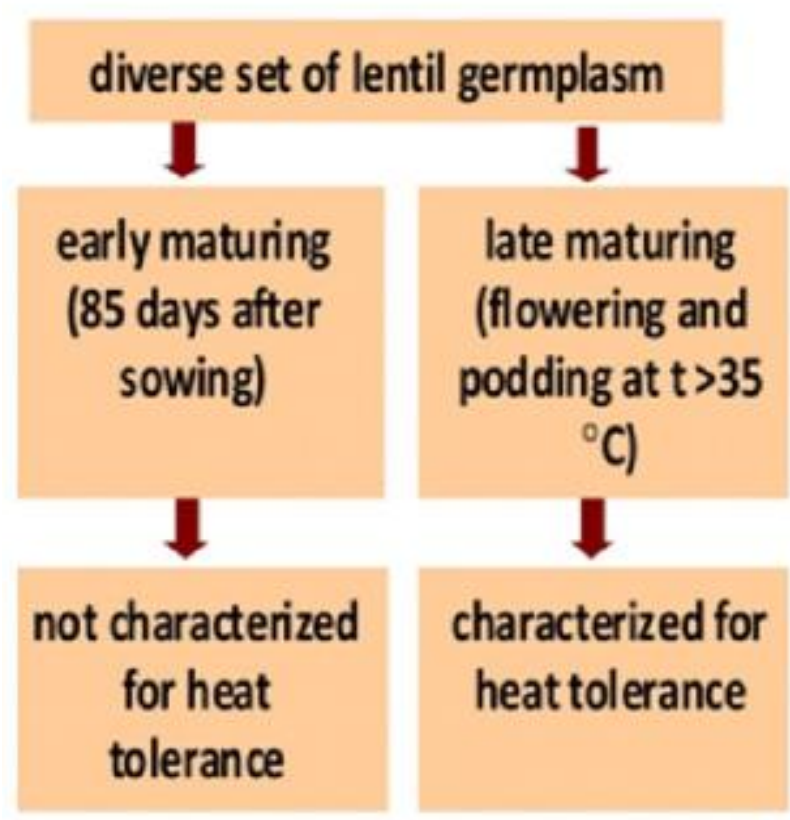

Figure 1 Technique used to screen heat tolerant genotype in lentil under field conditions

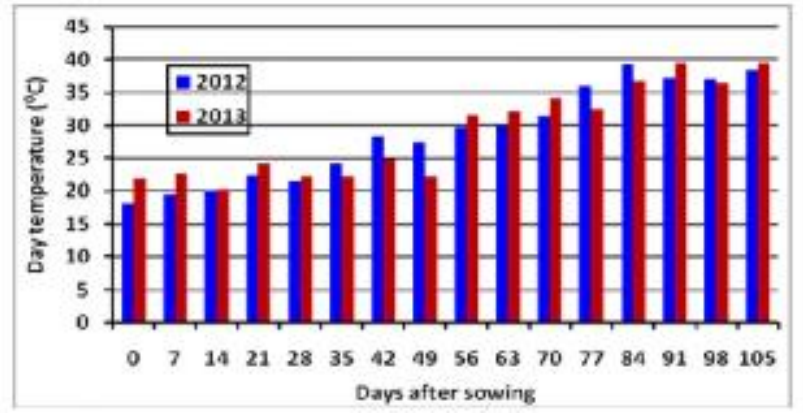

Figure 2 Standard weekly temperature over two years during January to March at experimental farm of IIPR, Kanpur 
The results indicated significant year effects on filled and unfilled pods/plant and hence wide variation in s.e.m over years. It was ranged from 0.2 to 37.8 for filled pods/plant and 0.0 to 16.5 for unfilled pods. Therefore, stable genotypes were identified with lower s. e. m. over the years along with highest pod formation per plant and on terminal branch.

Table 1 Mean with standard error of mean over the two years for 37 genotypes of lentil

\begin{tabular}{|c|c|c|c|c|c|c|}
\hline Accessions & DFF & $\mathrm{FP} / \mathrm{P}$ & UNFP/P & $\mathrm{FP} / \mathrm{TB}$ & UNFP/TB & $100 \mathrm{SW}$ \\
\hline PRECOZ & $6.5 \pm 0.50$ & $20.0 \pm 5.0$ & $9.5 \pm 0.5$ & $2.3 \pm 0.8$ & $1.0 \pm 1.0$ & $2.3 \pm 0.1$ \\
\hline FLIP2009-55L & $68.5 \pm 0.50$ & $43.7 \pm 3.7 *$ & $19.0 \pm 4.0$ & $8.3 \pm 0.8^{*}$ & $1.5 \pm 0.0$ & $2.5 \pm 0.2$ \\
\hline DPL-58 & $56 \pm 3.01$ & $38.2 \pm 1.2$ & $17.5 \pm 0.5$ & $3.3 \pm 0.3$ & $0.0 \pm 0.0$ & $2.5 \pm 0.1$ \\
\hline DPL-315 & $68.5 \pm 1.50$ & $13.0 \pm 7.0$ & $6.0 \pm 1.0$ & $4.0 \pm 0.5$ & $1.5 \pm 0.5$ & $2.1 \pm 0.0$ \\
\hline DPL-15 & $78 \pm 1.00$ & $13.8 \pm 5.9$ & $17.0 \pm 7.0$ & $3.0 \pm 1.0$ & $1.5 \pm 0.5$ & $2.0 \pm 0.1$ \\
\hline IG-2506 & $77 \pm 6.02$ & $5.7 \pm 0.7$ & $12.5 \pm 7.5$ & $3.0 \pm 0.5$ & $1.5 \pm 0.5$ & $1.8 \pm 0.1$ \\
\hline IG-2507 & $73.5 \pm 5.52$ & $43.7 \pm 8.7 *$ & $11.5 \pm 1.5$ & $7.0 \pm 2.0 *$ & $2.3 \pm 0.8$ & $1.7 \pm 0.2$ \\
\hline IG-2510 & $72.5 \pm 3.51$ & $8.2 \pm 0.2$ & $14.0 \pm 4.0$ & $2.3 \pm 0.3$ & $1.5 \pm 0.5$ & $1.6 \pm 0.1$ \\
\hline IG-2519 & $74 \pm 5.01$ & $6.2 \pm 1.2$ & $23.5 \pm 3.5$ & $3.5 \pm 0.0$ & $0.5 \pm 0.0$ & $2.0 \pm 0.0$ \\
\hline IG-2525 & $73 \pm 6.02$ & $8.0 \pm 2.0$ & $16.0 \pm 0.0$ & $2.3 \pm 0.8$ & $1.3 \pm 1.3$ & $1.4 \pm 0.3$ \\
\hline IG-2580 & $73.5 \pm 0.50$ & $3.3 \pm 0.3$ & $20.0 \pm 1.0$ & $4.3 \pm 1.8$ & $1.8 \pm 0.8$ & $1.6 \pm 0.3$ \\
\hline IG-2802 & $74.5 \pm 2.51$ & $6.7 \pm 2.7$ & $10.0 \pm 2.0$ & $1.5 \pm 0.5$ & $1.3 \pm 0.3$ & $1.4 \pm 0.1$ \\
\hline IG-2820 & $76 \pm 0.00$ & $8.7 \pm 0.7$ & $20.0 \pm 7.0$ & $3.8 \pm 1.3$ & $2.5 \pm 0.5$ & $2.0 \pm 0.2$ \\
\hline IG-2821 & $72.5 \pm 0.50$ & $11.3 \pm 2.7$ & $23.5 \pm 16.5$ & $3.8 \pm 0.3$ & $1.8 \pm 0.8$ & $1.6 \pm 0.1$ \\
\hline IG-2849 & $73 \pm 3.01$ & $12.5 \pm 2.5$ & $26.0 \pm 6.0$ & $1.8 \pm 0.8$ & $0.8 \pm 0.8$ & $1.9 \pm 0.1$ \\
\hline IG-2878 & $73.5 \pm 3.51$ & $7.7 \pm 0.7$ & $22.5 \pm 0.5$ & $2.0 \pm 1.0$ & $1.5 \pm 0.5$ & $1.7 \pm 0.1$ \\
\hline IG-3263 & $75 \pm 1.00$ & $42.0 \pm 36.1$ & $23.0 \pm 0.0$ & $3.5 \pm 0.5$ & $2.0 \pm 1.0$ & $2.0 \pm 0.1$ \\
\hline IG-3290 & $75 \pm 1.00$ & $7.2 \pm 0.8$ & $9.5 \pm 2.5$ & $3.3 \pm 0.3$ & $0.0 \pm 0.0$ & $1.9 \pm 0.1$ \\
\hline IG-3297 & $72 \pm 4.01$ & $30.5 \pm 8.5$ & $15.0 \pm 3.0$ & $3.0 \pm 0.0$ & $0.0 \pm 0.0$ & $1.6 \pm 0.2$ \\
\hline IG-3312 & $71 \pm 2.01$ & $40.8 \pm 5.9$ & $26.0 \pm 12.0$ & $2.0 \pm 0.0$ & $0.0 \pm 0.0$ & $2.3 \pm 0.2$ \\
\hline IG-3326 & $75 \pm 1.00$ & $15.8 \pm 0.8$ & $21.5 \pm 3.5$ & $4.3 \pm 0.8$ & $0.5 \pm 0.5$ & $1.6 \pm 0.2$ \\
\hline IG-3327 & $77.5 \pm 1.50$ & $43.3 \pm 1.3^{*}$ & $16.5 \pm 1.5$ & $1.8 \pm 0.8$ & $0.0 \pm 0.0$ & $1.8 \pm 0.2$ \\
\hline IG-3330 & $76.5 \pm 2.51$ & $45.5 \pm 23.6^{*}$ & $37.0 \pm 7.0$ & $4.0 \pm 1.0$ & $2.5 \pm 0.5$ & $1.7 \pm 0.3$ \\
\hline IG-3364 & $80.5 \pm 6.52$ & $8.5 \pm 3.5$ & $45.0 \pm 12.0$ & $4.8 \pm 0.8$ & $1.3 \pm 0.3$ & $1.8 \pm 0.3$ \\
\hline IG-3520 & $72.5 \pm 2.51$ & $26.7 \pm 6.7$ & $16.5 \pm 2.5$ & $3.0 \pm 0.5$ & $0.5 \pm 0.5$ & $1.9 \pm 0.1$ \\
\hline IG-3537 & $79.5 \pm 3.51$ & $28.7 \pm 6.4$ & $15.5 \pm 5.5$ & $2.5 \pm 0.5$ & $0.5 \pm 0.5$ & $2.1 \pm 0.0$ \\
\hline IG-3546 & $74.5 \pm 2.51$ & $47.2 \pm 2.8^{*}$ & $28.5 \pm 0.5$ & $3.3 \pm 0.8$ & $3.8 \pm 0.3 *$ & $1.1 \pm 0.7$ \\
\hline IG-3568 & $81.5 \pm 6.52$ & $4.8 \pm 1.8$ & $43.0 \pm 5.0$ & $1.8 \pm 0.3$ & $0.3 \pm 0.3$ & $1.2 \pm 0.0$ \\
\hline IG-3641 & $84.5 \pm 4.51$ & $25.8 \pm 10.9$ & $15.0 \pm 3.0$ & $2.5 \pm 0.0$ & $1.5 \pm 0.0$ & $1.5 \pm 0.1$ \\
\hline IG-3745 & $85.5 \pm 10.53$ & $51.2 \pm 11.2 *$ & $27.0 \pm 2.0$ & $2.0 \pm 0.0$ & $1.8 \pm 0.8$ & $1.9 \pm 0.0$ \\
\hline IG-3803 & $83.5 \pm 12.54$ & $22.2 \pm 7.2$ & $21.0 \pm 1.0$ & $2.8 \pm 0.3$ & $1.3 \pm 0.3$ & $2.3 \pm 0.4$ \\
\hline IG-3984 & $84 \pm 12.04$ & $28.5 \pm 0.5$ & $5.5 \pm 2.5$ & $8.0 \pm 4.0^{*}$ & $2.3 \pm 0.3 *$ & $1.7 \pm 0.1$ \\
\hline IG-4221 & $68 \pm 2.01$ & $8.8 \pm 1.2$ & $28.0 \pm 4.0$ & $5.3 \pm 0.8$ & $0.8 \pm 0.8$ & $1.3 \pm 0.2$ \\
\hline IG-4242 & $82 \pm 7.02$ & $17.3 \pm 10.4$ & $29.5 \pm 16.5$ & $4.3 \pm 0.8$ & $0.8 \pm 0.8$ & $1.5 \pm 0.1$ \\
\hline IG-4258 & $75.5 \pm 0.50$ & $47.7 \pm 37.8^{*}$ & $30.5 \pm 14.5$ & $10.0 \pm 2.0^{*}$ & $3.0 \pm 1.0 *$ & $2.3 \pm 0.2$ \\
\hline IG-4318 & $67.5 \pm 0.50$ & $31.2 \pm 21.2$ & $16.0 \pm 4.0$ & $4.8 \pm 0.3$ & $1.5 \pm 0.5$ & $1.6 \pm 0.2$ \\
\hline IG-5146 & $78 \pm 8.02$ & $47.7 \pm 2.7 *$ & $14.0 \pm 4.0$ & $1.8 \pm 0.8$ & $1.3 \pm 1.3$ & $2.3 \pm 0.1$ \\
\hline Mean & 74.8 & 23.43 & 20.32 & 3.62 & 1.3 & 1.82 \\
\hline Range (mean) & $56-85$ & $3.3-51.2$ & $5.5-45.0$ & $0.0-3.8$ & $1.5-10.0$ & $1.1-2.5$ \\
\hline s.e.m & 5.50 & 9.35 & 9.05 & 1.42 & 0.85 & 0.28 \\
\hline Range (s.e.m) & $0.0-12.5$ & $0.2-37.8$ & $0.0-16.5$ & $0.0-1.3$ & $0.0-2.0$ & $0.0-0.7$ \\
\hline $\mathrm{CD}$ (at & 11.16 & 18.96 & 18.40 & 2.87 & 1.72 & 0.56 \\
\hline $\mathrm{CV}(\%)$ & 7.35 & 39.91 & 44.54 & 39.14 & 66.50 & 15.19 \\
\hline
\end{tabular}




\section{Legume Genomics and Genetics 2016, Vol.7, No.1, 1-11}

\subsection{Identification of heat tolerant genotypes}

In the present study, eight genotypes FLIP2009-55L (43.7) IG2507 (43.7), IG3327 (43.3), IG 3330 (45.5), IG 3546 (47.2), IG 3745 (51.2), IG 4258 (47.7) and IG 5146 (47.7) had significantly large number of filled pods per plant at higher temperature $\left(>35^{\circ} \mathrm{C}\right)$. Also, genotypes, namely, IG2507 (7.0), IG 3984 (8.0), FLIP2009-55L (8.3), and IG4258 (10.0) had significantly more number of filled pods on terminal branch. However, significantly large numbers of unfilled pods were observed in IG3330 (37.0), IG 3364 (45.0), IG3546 (28.5), IG 4242 (29.5) and

Table 2 Mean and critical difference (CD) of heat tolerant lentil genotypes and their pollen viability

\begin{tabular}{lllllll}
\hline Genotype & FP/P & UFP/P & FP on TB & UFP on TB & $\begin{array}{l}\text { Reduction in } \\
100-S W(\%)\end{array}$ & $\begin{array}{l}\text { Pollen viability } \\
(\%)\end{array}$ \\
\hline IG-4258 & 47.67 & 30.5 & $10^{* *}$ & $3 * *$ & 28.3 & 60.9 \\
IG-2507 & 43.67 & 11.5 & $7^{* *}$ & 2 & 26.2 & 72.4 \\
FLIP2009-55L & 43.67 & 19 & $8.25^{* *}$ & 2 & 5.7 & 63.2 \\
CD (P=0.05) & 19.96 & 18.4 & 2.8 & 1.7 & - & - \\
\hline
\end{tabular}

Note- FP/P = filled pods/plant; UFP/P =unfilled pods/plant; FP on TB= filled pods on terminal branch; UFP at TB= unfilled pods on terminal branch

IG 4258 (30.5). Based on these observations, only three genotypes, FLIP2009-55L, IG2507 and IG4258 were identified as heat tolerance genotypes because these three genotypes had significantly more number of filled pods per plant as well as on terminal branch of each individual plant. These genotypes also had significantly less number of unfilled pods/plant except on IG4258 (Table 3). In order to see the impact of late-sown conditions on seed size, data were recorded on 100-SW under late- and normal-sown conditions. The percent reduction in seed size observed under late-sown condition is presented in Figure 3. It ranged from $2.4 \%$ to $67.2 \%$. This was lowest in IG 4242 (2.4\%) and highest in ILL 6002 (67.2\%). However, three heat tolerant genotypes FLIP2009-55L, IG2507 and IG4258 had reduction in seed size 5.7\%, 26.2\% and $28.3 \%$, respectively (Table 2 ). The pollen viability was used as physiological trait and tested in laboratory by collecting pollens at higher temperature $\left(>35^{\circ} \mathrm{C}\right)$. The pollen viability of FLIP2009-55L, IG2507 and IG4258 was $63.2 \%, 72.4 \%$ and $60.9 \%$, respectively (Table 2 ). Pollen viability showed significant positive correlation with filled pods/plant $(\mathrm{r}=0.79)$.

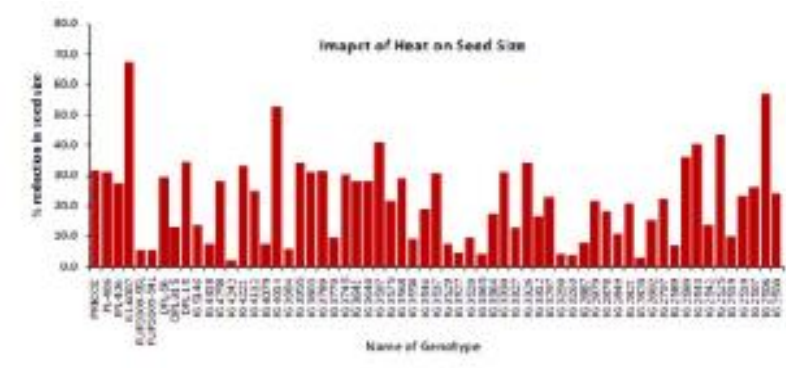

Figure 3 Effect of heat on seed size in 37 lentil accessions

Table 3 Combined ANOVA for different traits under late sown conditions (2011-12 and 2012-13)

\begin{tabular}{|c|c|c|c|c|c|c|c|}
\hline \multirow{2}{*}{$\begin{array}{l}\text { Sources of } \\
\text { Variation }\end{array}$} & \multirow[t]{2}{*}{ DF } & \multicolumn{6}{|c|}{ Mean of Squares } \\
\hline & & DFF & TUFP/P & $\mathrm{TFP} / \mathrm{P}$ & FP on TB & UFP on TB & 100-SW \\
\hline Year & 1 & $648.12 * *$ & 39.49 & $1179.74 * *$ & 7.15 & 0.41 & 0.25 \\
\hline Genotype & 36 & $68.17 * *$ & $167.23^{*}$ & $555.67 * *$ & $7.59 * *$ & $1.56^{* *}$ & $0.24 * *$ \\
\hline Error & 36 & 30.29 & 81.96 & 87.41 & 2.01 & 0.72 & 0.08 \\
\hline $\begin{array}{l}\text { Heritability } \\
(\%)\end{array}$ & & 38.48 & 8.94 & 46.31 & 58.13 & 36.84 & 50 \\
\hline
\end{tabular}

Note: $* \mathrm{P}<0.05, * * \mathrm{P}<0.01$ 


\section{Legume Genomics and Genetics 2016, Vol.7, No.1, 1-11}

\section{Discussion}

In India, temperature fluctuation during the grain filling period causes drastic yield losses in cool-season legumes. In chickpea, grain yields is estimated to reduce by $53-301 \mathrm{~kg} / \mathrm{ha}$ if mean temperature rises $1{ }^{\circ} \mathrm{C}$ (Kalra et al., 2008). Photoperiod and temperature are the major factors affecting flowering initiation in crop plants. Pulses are particularly sensitive to heat at flowering and pod development stages. If the crop encounters a few days of exposure to high temperatures $\left(30-35^{\circ} \mathrm{C}\right)$ at these stages, heavy yield losses are reported due to flower drop and pod abortion (Summerfield et al., 1985; Sarker et al., 1999; Roberts et al., 1986; Gopesh et al., 2013). However, this sensitivity varies from genotype to genotype. The temperature during the reproductive stage in both years of experimentation was above the threshold level $\left(>30^{\circ} \mathrm{C}\right.$; Figure 2$)$, which suggested suitable conditions for identification of heat tolerant genotypes in lentil. Similar environmental conditions have also been used earlier to screen heat tolerant genotypes in chickpea (Krishnamurthy et al., 2011). Based on flowering and podding under higher temperature, in the present study, lentil genotypes were clearly categorized into three main groups, (i) early flowering, (ii) no flowering or rarely flowering and (iii) normal flowering and pod setting. In the present study 174 genotypes flowered early and matured within 80-85 days after sowing. Because these genotypes escaped from high temperature conditions and hence excluded from screening studies conducted further in next year. Earlier studies showed that heat stress delays flowering and accelerates maturity (Krishnamurthy et al., 2011) and hence probably due to this, 64 accessions in the present study did not flower or flowered rarely. The degree of tolerance was studied among 37 genotypes, which had filled and unfilled pods on individual plant as well as on terminal branch. The combined analysis of variance showed significant genetic variability for heat tolerance among these genotypes for filled pods/plant, unfilled pods/plant, filled and unfilled pods on terminal branch, $50 \%$ flowering and 100-SW. Similarly, genetic variation for heat tolerance among chickpea genotypes was reported (Krishnamurthy et al., 2011).

Heritability determines the proportion of parental characters that is inherited to their off-springs and hence it is an important parameter to study the inheritance of quantitative characters (Allard, 1960). A trait with high heritability suggests maximum genetic gain in response of selection and can be used reliably for screening the tolerant genotypes under heat stress conditions. In the present investigation, we observed high heritability for filled pods/plant and filled pods on terminal branch. Therefore, these traits could be useful to select tolerant genotypes at higher temperature. Lucas et al. (2012) also used number of pods per peduncle for identification of heat tolerance in recombinant inbred lines population of cowpea. In the present study, three genotypes, IG 3745, IG 4258 and IG 5146 were identified as heat tolerant because these accessions had significantly more pods per plant (>43 pods/plant) at higher temperature. On the basis of the number of pods on the terminal branch at higher temperature, FLIP2009-55L, IG2507 and IG4258 showed more number of pods on terminal branch and thus highly heat tolerant. Though another genotype (IG-3984) also showed more pod formation on terminal branch, it was poor in total number of effective pods per plant. We observed significantly higher unfilled pods for some genotypes, indicating the impacts of high temperature on pod formation. In legumes high temperature during anthesis reduces seed set due to impaired pollen tube growth and fertilization (Gross and Kigel, 1994).

The present study showed instability in performance of filled pods/plant over the years in most of the genotypes. The combined analysis of variation for filled pods/plant reflected that a large proportion of total phenotypic variance was due to environmental factors. In pulses, environment and genotype $\times$ environment interactions contribute $>70 \%$ of total phenotypic variance as reported earlier (Kumar and Ali, 2006). However, two genotypes (i.e. FLIP2009-55L and IG2507) that classified as highly tolerant to heat showed stable performance over the years as reflected by low s.e.m. These genotypes can be used in lentil breeding program for developing improved cultivars having tolerance to terminal heat.

In the present investigation, impacts of high temperature were also observed on seed size, which varied from $2.4 \%$ to $67.2 \%$ over the normal sown conditions. However heat tolerant genotypes showed $5.7 \%$ to $28.3 \%$ reduction in seed size which is 
comparatively lower than other genotypes due to efficient accumulation of photosynthesis in seeds during grain filling at higher temperature. Though a few days of exposure to high temperatures $\left(30-35^{\circ} \mathrm{C}\right)$ during seed filling accelerates senescence, diminish seed set and seed weight, and reduce yield in pluses (Siddique et al., 1999), different genotypes within a species have different capabilities in coping with the heat stress (Wahid et al., 2007).

High temperature leads pollen sterility (Saini et al., 1984) and hence seed yield depends on the temperature during pollen development (Ploeg Van der and Heuvelink, 2005). In the present study, high pollen viability (60-70\%) was observed for two heat tolerant genotypes (FLIP2009-55L and IG2507) and showed highly positive correlation with number of pods per plant. Our results suggest that pollen viability test could be used in laboratory for identification of heat tolerant genotypes in lentil. The impact of heat stress on pollen viability has already been demonstrated in several legume crops including chickpea, common bean, groundnut, and soybean (Prasad et al., 1999; Porch and Jahn, 2001; Devasirvatham et al., 2012; Djanaguirama et al., 2013).

\section{Conclusion}

The present investigation shows that heat stress significantly affects number of flowers, pods, and seeds. Therefore, filled and unfilled pods on a single plant basis and on the terminal branch are important traits for phenotyping heat tolerance under field conditions. Further, the pollen viability is a useful trait for identification of heat tolerant genotype in lentil. Our results clearly demonstrated that significant genetic variability exits for these morphological traits in cultivated gene-pool of lentil. These genotypes can be considered as potential genetic resources to be used in lentil breeding program for the development of heat tolerant cultivars.

\section{Materials and Methods}

\subsection{Plant materials}

The present study included 334 lentil genotypes representing local and exotic germplasm originating from drought-prone areas, elite breeding lines from national and international programs and improved cultivars released in India. Breeding lines used in this study were developed at the Indian Institute of Pulses Research (IIPR), Kanpur, India. These lines are derived from crosses involving parents adapted to terminal heat-prone environments. These accessions were evaluated in 2011-12 and 160 accessions (out of above 334 accessions) that faced high temperature $\left(>35{ }^{\circ} \mathrm{C}\right)$ during reproductive stage were again screened for heat tolerance in 2012-13 (Table 4).

Table 4 Description of pedigree/collection number and collecting/breeding organization of 160 lentil accessions used over two years (2011-12 and 2012-13) in the present study

\begin{tabular}{|c|c|c|c|}
\hline S.No & $\begin{array}{l}\text { Accessi } \\
\text { on }\end{array}$ & $\begin{array}{l}\text { Pedigree/Collect } \\
\text { ion Number }\end{array}$ & $\begin{array}{l}\text { Collecting/ } \\
\text { Breeding } \\
\text { organization }\end{array}$ \\
\hline 1 & $\begin{array}{l}\mathrm{IG} \\
2500\end{array}$ & PANT-L 538 & $\begin{array}{l}\text { GBPUAT, } \\
\text { Pantnagar }\end{array}$ \\
\hline 2 & $\begin{array}{l}\text { IG } \\
2506\end{array}$ & PANT-L 643 & $\begin{array}{l}\text { GBPUAT, } \\
\text { Pantnagar }\end{array}$ \\
\hline 3 & $\begin{array}{l}\text { IG } \\
2507\end{array}$ & LL 3 & $\begin{array}{l}\text { PAU, Ludhiana, } \\
\text { Punjab }\end{array}$ \\
\hline 4 & $\begin{array}{l}\text { IG } \\
2508\end{array}$ & LL 5 & $\begin{array}{l}\text { PAU, Ludhiana, } \\
\text { Punjab }\end{array}$ \\
\hline 5 & $\begin{array}{l}\text { IG } \\
2510\end{array}$ & LL 25 & $\begin{array}{l}\text { PAU, Ludhiana, } \\
\text { Punjab }\end{array}$ \\
\hline 6 & $\begin{array}{l}\text { IG } \\
2519\end{array}$ & PUSA 9 & IARI New Delhi \\
\hline 7 & $\begin{array}{l}\text { IG } \\
2525\end{array}$ & T 31 & IARI-RS, Kanpur \\
\hline 8 & $\begin{array}{l}\text { IG } \\
2542\end{array}$ & L 543 & unknown \\
\hline 9 & $\begin{array}{l}\text { IG } \\
2543\end{array}$ & L 546 & unknown \\
\hline 10 & $\begin{array}{l}\text { IG } \\
2576\end{array}$ & L 771 & unknown \\
\hline 11 & $\begin{array}{l}\text { IG } \\
2580\end{array}$ & L 1278 & unknown \\
\hline 12 & $\begin{array}{l}\text { IG } \\
2588\end{array}$ & LWS 1 & $\begin{array}{l}\text { JNKVV, Jabalpur, } \\
\text { UP }\end{array}$ \\
\hline 13 & $\begin{array}{l}\text { IG } \\
2589\end{array}$ & LWS 2 & $\begin{array}{l}\text { JNKVV, Jabalpur, } \\
\text { UP }\end{array}$ \\
\hline 14 & $\begin{array}{l}\text { IG } \\
2593\end{array}$ & LWS 6 & $\begin{array}{l}\text { JNKVV, Jabalpur, } \\
\text { UP }\end{array}$ \\
\hline 15 & $\begin{array}{l}\text { IG } \\
2796\end{array}$ & P 287 & $\begin{array}{l}\text { USDA,-RPIP, New } \\
\text { Delhi }\end{array}$ \\
\hline 16 & $\begin{array}{l}\text { IG } \\
2797\end{array}$ & P 290 & $\begin{array}{l}\text { USDA,-RPIP, New } \\
\text { Delhi }\end{array}$ \\
\hline 17 & $\begin{array}{l}\text { IG } \\
2802\end{array}$ & P 300 & $\begin{array}{l}\text { USDA,-RPIP, New } \\
\text { Delhi }\end{array}$ \\
\hline 18 & $\begin{array}{l}\text { IG } \\
2817\end{array}$ & P 326 & $\begin{array}{l}\text { USDA,-RPIP, New } \\
\text { Delhi }\end{array}$ \\
\hline
\end{tabular}




\begin{tabular}{|c|c|c|c|c|c|c|c|c|c|}
\hline \multirow{2}{*}{19} & IG & \multirow[t]{2}{*}{ P 332} & & \multicolumn{2}{|c|}{ USDA,-RPIP, New } & 45 & IG & LL 30 & PAU, Ludhiana, \\
\hline & 2820 & & & \multicolumn{2}{|c|}{ Delhi } & & 3587 & & Punjab \\
\hline \multirow[t]{2}{*}{20} & IG & \multirow[t]{2}{*}{ Р 333} & & \multicolumn{2}{|c|}{ USDA,-RPIP, New } & 46 & IG & NP 22 & IARI, New Delhi \\
\hline & 2821 & & & \multicolumn{2}{|l|}{ Delhi } & & 3640 & & \\
\hline \multirow[t]{2}{*}{21} & IG & \multirow[t]{2}{*}{ P 368} & & \multicolumn{2}{|c|}{ USDA,-RPIP, New } & 47 & IG & NP 47 & IARI, New Delhi \\
\hline & 2849 & & & \multicolumn{2}{|l|}{ Delhi } & & 3641 & & \\
\hline \multirow[t]{2}{*}{22} & IG & \multirow[t]{2}{*}{ P 405} & & \multicolumn{2}{|c|}{ USDA,-RPIP, New } & 48 & IG & NP 52 & IARI, New Delhi \\
\hline & 2878 & & & \multicolumn{2}{|l|}{ Delhi } & & 3643 & & \\
\hline \multirow[t]{2}{*}{23} & IG & \multirow[t]{2}{*}{ P 406} & & USDA, & RPIP, New & 49 & IG & P 27 & USDA,-RPIP, New \\
\hline & 2879 & & & Delhi & & & 3676 & & Delhi \\
\hline 24 & IG & P 422 & & USDA, & RPIP, New & 50 & IG & P 175 & USDA,-RPIP, New \\
\hline & 2887 & & & Delhi & & & 3745 & & Delhi \\
\hline 25 & IG & P 912 & & USDA, & RPIP, New & 51 & IG & P 206 & USDA,-RPIP, New \\
\hline & 3253 & & & Delhi & & & 3770 & & Delhi \\
\hline 26 & DPL-58 & PL $\quad 639$ & $x$ & IIPR, K & npur & 52 & IG & P 227 & USDA,-RPIP, New \\
\hline & & PRECOZ & & & & & 3789 & & Delhi \\
\hline 27 & IG & P 949 & & USDA, & RPIP, New & 53 & IG & P 241 & USDA,-RPIP, New \\
\hline & 3286 & & & Delhi & & & 3803 & & Delhi \\
\hline 28 & IG & P 956 & & USDA, & RPIP, New & 54 & IG & P 437 & USDA,-RPIP, New \\
\hline & 3290 & & & Delhi & & & 3955 & & Delhi \\
\hline 29 & IG & P 988 & & USDA, & RPIP, New & 55 & IG & P 480 & USDA,-RPIP, New \\
\hline & 3297 & & & Delhi & & & 3984 & & Delhi \\
\hline 30 & IG & P 1020 & & USDA, & RPIP, New & 56 & IG & P 505 & USDA,-RPIP, New \\
\hline & 3312 & & & Delhi & & & 4001 & & Delhi \\
\hline 31 & IG & P 1046 & & USDA, & RPIP, New & 57 & IG & P 524 & USDA,-RPIP, New \\
\hline & 3326 & & & Delhi & & & 4014 & & Delhi \\
\hline 32 & IG & P 1047 & & USDA, & RPIP, New & 58 & IG & P 629 & USDA,-RPIP, New \\
\hline & 3327 & & & Delhi & & & 4068 & & Delhi \\
\hline 33 & IG & P 1050 & & USDA, & RPIP, New & 59 & IG & P 633 & USDA,-RPIP, New \\
\hline & 3330 & & & Delhi & & & 4072 & & Delhi \\
\hline 34 & IG & P LWS 16 & & JNKVV & Jabalpur, & 60 & IG & P 640 & USDA,-RPIP, New \\
\hline & 3370 & & & & & & 4079 & & Delhi \\
\hline 35 & IG & PI 42 & & USDA, & RPIP, New & 61 & IG & P 701 & USDA,-RPIP, New \\
\hline & 3365 & & & Delhi & & & 4112 & & Delhi \\
\hline 36 & IG & LG 74 & & PAU, & Ludhiana, & 62 & IG & Р 702 & USDA,-RPIP, New \\
\hline & 3520 & & & Punjab & & & 4113 & & Delhi \\
\hline 37 & IG & LG 112 & & PAU, & Ludhiana, & 63 & IG & P 773 & USDA,-RPIP, New \\
\hline & 3527 & & & Punjab & & & 4147 & & Delhi \\
\hline 38 & IG & LG 116 & & PAU, & Ludhiana, & 64 & IG & P 886 & USDA,-RPIP, New \\
\hline & 3529 & & & Punjab & & & 4202 & & Delhi \\
\hline 39 & IG & LG 141 & & PAU, & Ludhiana, & 65 & IG & P 887 & USDA,-RPIP, New \\
\hline & 3537 & & & Punjab & & & 4203 & & Delhi \\
\hline 40 & IG & LG 150 & & PAU, & Ludhiana, & 66 & IG & P 891 & USDA,-RPIP, New \\
\hline & 3546 & & & Punjab & & & 4206 & & Delhi \\
\hline 41 & IG & LG 162 & & PAU, & Ludhiana, & 67 & IG & P 894 & USDA,-RPIP, New \\
\hline & 3558 & & & Punjab & & & 4208 & & Delhi \\
\hline 42 & IG & LL 1 & & PAU, & Ludhiana, & 68 & IG & P 916 & USDA,-RPIP, New \\
\hline & 3567 & & & Punjab & & & 4219 & & Delhi \\
\hline 43 & IG & LL 3 & & PAU, & Ludhiana, & 69 & IG & P 924 & USDA,-RPIP, New \\
\hline & 3568 & & & Punjab & & & 4221 & & Delhi \\
\hline 44 & IG & LL 23 & & PAU, & Ludhiana, & 70 & IG & P 957 & USDA,-RPIP, New \\
\hline & 3575 & & & Punjab & & & 4242 & & Delhi \\
\hline
\end{tabular}




\begin{tabular}{|c|c|c|c|c|c|c|c|}
\hline 71 & IG & P 959 & USDA,-RPIP, New & & 6 & $157634 / 382$ & \\
\hline 72 & $\begin{array}{l}4243 \\
\text { IG }\end{array}$ & P 967 & $\begin{array}{l}\text { Delhi } \\
\text { USDA,-RPIP, New }\end{array}$ & 97 & $\begin{array}{l}\text { IPL-31 } \\
5\end{array}$ & PL $4 \times$ DPL 62 & IIPR, Kanpur \\
\hline & 4246 & & Delhi & 98 & IG & P 41 & USDA,-RPIP, New \\
\hline 73 & IG & P 971 & USDA,-RPIP, New & & 2639 & & Delhi \\
\hline 74 & $\begin{array}{l}4247 \\
\mathrm{IG}\end{array}$ & P 985 & $\begin{array}{l}\text { Delhi } \\
\text { USDA,-RPIP, New }\end{array}$ & 99 & $\begin{array}{l}\text { IG } \\
2649\end{array}$ & P 55 & $\begin{array}{l}\text { USDA,-RPIP, New } \\
\text { Delhi }\end{array}$ \\
\hline 75 & $\begin{array}{l}4258 \\
\text { IG }\end{array}$ & P 1036 & $\begin{array}{l}\text { Delhi } \\
\text { USDA,-RPIP, New }\end{array}$ & 100 & $\begin{array}{l}\text { IG } \\
2794\end{array}$ & P 285 & $\begin{array}{l}\text { USDA,-RPIP, New } \\
\text { Delhi }\end{array}$ \\
\hline 76 & $\begin{array}{l}4278 \\
\mathrm{IG}\end{array}$ & P 1047 & $\begin{array}{l}\text { Delhi } \\
\text { USDA,-RPIP, New }\end{array}$ & 101 & $\begin{array}{l}\text { IG } \\
2836\end{array}$ & P 353 & $\begin{array}{l}\text { USDA,-RPIP, New } \\
\text { Delhi }\end{array}$ \\
\hline 77 & $\begin{array}{l}4284 \\
\mathrm{IG}\end{array}$ & P 1132 & $\begin{array}{l}\text { Delhi } \\
\text { USDA,-RPIP, New }\end{array}$ & 102 & $\begin{array}{l}\text { IG } \\
3072\end{array}$ & P 720 & $\begin{array}{l}\text { USDA,-RPIP, New } \\
\text { Delhi }\end{array}$ \\
\hline 78 & $\begin{array}{l}4318 \\
\text { IG5146 }\end{array}$ & LC 33 & $\begin{array}{l}\text { Delhi } \\
\text { POSRS, }\end{array}$ & 103 & $\begin{array}{l}\text { IG } \\
3563\end{array}$ & LG 167 & $\begin{array}{l}\text { PAU, Ludhiana, } \\
\text { Punjab }\end{array}$ \\
\hline 79 & ILL & ILL 8090 X ILL & $\begin{array}{l}\text { Berhampore,WB } \\
\text { ICARDA }\end{array}$ & 104 & $\begin{array}{l}\text { IG } \\
3589\end{array}$ & LL 31 & $\begin{array}{l}\text { PAU, Ludhiana, } \\
\text { Punjab }\end{array}$ \\
\hline 80 & $\begin{array}{l}10965 \\
\text { ILL }\end{array}$ & $\begin{array}{l}7980 \\
\text { ILL } 7723 \text { X ILL }\end{array}$ & ICARDA & 105 & $\begin{array}{l}\text { IG } \\
3662\end{array}$ & P 10 & $\begin{array}{l}\text { USDA,-RPIP, New } \\
\text { Delhi }\end{array}$ \\
\hline 81 & $\begin{array}{l}10969 \\
\text { ILL }\end{array}$ & $\begin{array}{l}8090 \\
\text { ILL6783 X ILL }\end{array}$ & ICARDA & 106 & $\begin{array}{l}\text { IG } \\
3667\end{array}$ & P 15 & $\begin{array}{l}\text { USDA,-RPIP, New } \\
\text { Delhi }\end{array}$ \\
\hline 82 & $\begin{array}{l}10712 \\
\text { ILL }\end{array}$ & $\begin{array}{l}98 \\
\text { ILL } 7012 \text { X ILL }\end{array}$ & ICARDA & 107 & $\begin{array}{l}\text { IG } \\
3673\end{array}$ & P 23 & $\begin{array}{l}\text { USDA,-RPIP, New } \\
\text { Delhi }\end{array}$ \\
\hline 83 & $\begin{array}{l}10711 \\
\text { L-9-12 }\end{array}$ & $\begin{array}{l}4404 \\
\text { Selection from loc }\end{array}$ & al variety & 108 & $\begin{array}{l}\text { IG } \\
3750\end{array}$ & P 183 & $\begin{array}{l}\text { USDA,-RPIP, New } \\
\text { Delhi }\end{array}$ \\
\hline 84 & $\mathrm{~T}-36$ & $\begin{array}{l}\text { Local selection } \\
\text { from Badaun, } \\
\text { UP }\end{array}$ & CSAUAT, Kanpur & 110 & $\begin{array}{l}\text { IG } \\
3794 \\
\text { IG }\end{array}$ & $\begin{array}{l}\text { P } 232 \\
\text { P } 239\end{array}$ & $\begin{array}{l}\text { USDA,-RPIP, New } \\
\text { Delhi } \\
\text { USDA,-RPIP, New }\end{array}$ \\
\hline 85 & PL-406 & Selection of P45 & $\begin{array}{l}\text { GBPUAT, } \\
\text { Pantnagar }\end{array}$ & 111 & $\begin{array}{l}3801 \\
\text { IG }\end{array}$ & P 240 & $\begin{array}{l}\text { Delhi } \\
\text { USDA,-RPIP, New }\end{array}$ \\
\hline 86 & JL-1 & $\begin{array}{l}\text { Local selection } \\
\text { from Madhya } \\
\text { Pradesh }\end{array}$ & JNKVP, Jabalpur & 112 & $\begin{array}{l}3802 \\
\mathrm{IG} \\
3905\end{array}$ & P 366 & $\begin{array}{l}\text { Delhi } \\
\text { USDA,-RPIP, New } \\
\text { Delhi }\end{array}$ \\
\hline 87 & $\begin{array}{l}\text { IPL-30 } \\
7\end{array}$ & $\begin{array}{l}\mathrm{L} 4076 \times \mathrm{DPL} \\
44\end{array}$ & IIPR, Kanpur & 113 & $\begin{array}{l}\text { IG } \\
3964\end{array}$ & $\mathrm{P} 450$ & $\begin{array}{l}\text { USDA,-RPIP, New } \\
\text { Delhi }\end{array}$ \\
\hline 88 & $\begin{array}{l}\text { IPL } \\
98 / 193\end{array}$ & $\begin{array}{ll}\text { (Sehore } & 74-3 \\
\text { DPL44) } & \times\end{array}$ & IIPR, Kanpur & 114 & $\begin{array}{l}\text { IG } \\
3973\end{array}$ & P 467 & $\begin{array}{l}\text { USDA,-RPIP, New } \\
\text { Delhi }\end{array}$ \\
\hline 89 & $\begin{array}{l}\text { SEHO } \\
\text { RE } \\
74-3\end{array}$ & $\begin{array}{l}\text { DPL35 } \\
\text { Local selection } \\
\text { from Sehore }\end{array}$ & JNKVP, Jabalpur & $\begin{array}{l}115 \\
116\end{array}$ & $\begin{array}{l}\text { IG } \\
3982 \\
\text { IG } \\
4000\end{array}$ & $\begin{array}{l}\text { P } 477 \\
\text { P } 504\end{array}$ & $\begin{array}{l}\text { USDA,-RPIP, New } \\
\text { Delhi } \\
\text { USDA,-RPIP, New } \\
\text { Delhi }\end{array}$ \\
\hline 90 & $\begin{array}{l}\text { ILL-60 } \\
02\end{array}$ & $\begin{array}{l}\mathrm{ILL} 4349 \times \mathrm{ILL} \\
4605\end{array}$ & ICADA, Syria & 117 & $\begin{array}{l}\text { IG } \\
4013\end{array}$ & P 523 & $\begin{array}{l}\text { USDA,-RPIP, New } \\
\text { Delhi }\end{array}$ \\
\hline 91 & $\begin{array}{l}\text { PRECO } \\
\mathrm{Z}\end{array}$ & $\begin{array}{l}\text { Argentina } \\
\text { cultivar }\end{array}$ & ICARDA & 118 & $\begin{array}{l}\text { IG } \\
4059\end{array}$ & P 613 & $\begin{array}{l}\text { USDA,-RPIP, New } \\
\text { Delhi }\end{array}$ \\
\hline 92 & L-4603 & $\begin{array}{l}\text { Precoz } \\
3991\end{array}$ & IARI, New Delhi & 119 & $\begin{array}{l}\text { IG } \\
4060\end{array}$ & P 617 & $\begin{array}{l}\text { USDA,-RPIP, New } \\
\text { Delhi }\end{array}$ \\
\hline 93 & DPL-15 & PL406 × L 4076 & IIPR, Kanpur & 120 & IG & Р 632 & USDA,-RPIP, New \\
\hline 94 & DPL-62 & JLS 1 x LG 171 & IIPR, Kanpur & & 4071 & & Delhi \\
\hline $\begin{array}{l}95 \\
96\end{array}$ & $\begin{array}{l}\text { IPL-81 } \\
\text { IPL-40 }\end{array}$ & $\begin{array}{l}\text { K } 75 \times \text { PL } 639 \\
\text { DPL } 35 \times \text { EC }\end{array}$ & $\begin{array}{l}\text { IIPR, Kanpur } \\
\text { IIPR, Kanpur }\end{array}$ & 121 & $\begin{array}{l}\text { IG } \\
4073\end{array}$ & P 634 & $\begin{array}{l}\text { USDA,-RPIP, New } \\
\text { Delhi }\end{array}$ \\
\hline
\end{tabular}




\begin{tabular}{|c|c|c|c|c|c|c|c|}
\hline 122 & $\begin{array}{l}\text { IG } \\
4074\end{array}$ & P 635 & $\begin{array}{l}\text { USDA,-RPIP, New } \\
\text { Delhi }\end{array}$ & 148 & $\begin{array}{l}\text { ILL } \\
10831\end{array}$ & $\begin{array}{l}\text { ILL } 2501 \times \text { ILL } \\
7537\end{array}$ & ICARDA, Syria \\
\hline 123 & $\begin{array}{l}\text { IG } \\
4076\end{array}$ & P 637 & $\begin{array}{l}\text { USDA,-RPIP, New } \\
\text { Delhi }\end{array}$ & 149 & $\begin{array}{l}\text { ILL } \\
10707\end{array}$ & $\begin{array}{l}\mathrm{ILL} 8090 \times \mathrm{ILL} \\
7685\end{array}$ & ICARDA, Syria \\
\hline 124 & $\begin{array}{l}\text { IG } \\
4078\end{array}$ & P 639 & $\begin{array}{l}\text { USDA,-RPIP, New } \\
\text { Delhi }\end{array}$ & 150 & $\begin{array}{l}\text { ILL } \\
10829\end{array}$ & $\begin{array}{l}\operatorname{ILL7620} \times \operatorname{ILL} \\
91517\end{array}$ & ICARDA, Syria \\
\hline 125 & $\begin{array}{l}\text { IG } \\
4098\end{array}$ & P 667 & $\begin{array}{l}\text { USDA,-RPIP, New } \\
\text { Delhi }\end{array}$ & 151 & $\begin{array}{l}\text { ILL } \\
10968\end{array}$ & $\begin{array}{l}\mathrm{ILL} 8090 \times \mathrm{ILL} \\
7980\end{array}$ & ICARDA, Syria \\
\hline 126 & $\begin{array}{l}\text { IG } \\
4149\end{array}$ & P 779 & $\begin{array}{l}\text { USDA,-RPIP, New } \\
\text { Delhi }\end{array}$ & 152 & $\begin{array}{l}\text { ILL } \\
10708\end{array}$ & $\begin{array}{l}\mathrm{ILL} 7617 \times \mathrm{ILL} \\
4404\end{array}$ & ICARDA, Syria \\
\hline 127 & $\begin{array}{l}\text { IG } \\
4195\end{array}$ & P 873 & $\begin{array}{l}\text { USDA,-RPIP, New } \\
\text { Delhi }\end{array}$ & 153 & $\begin{array}{l}\text { ILL } \\
10713\end{array}$ & $\begin{array}{l}\mathrm{ILL} 8077 \times \mathrm{ILL} \\
6994\end{array}$ & ICARDA, Syria \\
\hline 128 & $\begin{array}{l}\text { IG } \\
4197\end{array}$ & P 876 & $\begin{array}{l}\text { USDA,-RPIP, New } \\
\text { Delhi }\end{array}$ & 154 & $\begin{array}{l}\text { ILL } \\
10725\end{array}$ & $\begin{array}{l}\text { ILL } 7713 \times \text { ILL } \\
7201\end{array}$ & ICARDA, Syria \\
\hline 129 & $\begin{array}{l}\text { IG } \\
4216\end{array}$ & P 910 & $\begin{array}{l}\text { USDA,-RPIP, New } \\
\text { Delhi }\end{array}$ & 155 & $\begin{array}{l}\text { ILL } \\
10825\end{array}$ & $\begin{array}{l}\text { ILL } 7620 \times \operatorname{ILL} \\
91517\end{array}$ & ICARDA, Syria \\
\hline 130 & $\begin{array}{l}\text { IG } \\
4228\end{array}$ & P 934 & $\begin{array}{l}\text { USDA,-RPIP, New } \\
\text { Delhi }\end{array}$ & 156 & $\begin{array}{l}\text { ILL } \\
10827\end{array}$ & $\begin{array}{l}\text { ILL } 7620 \times \text { ILL } \\
91517\end{array}$ & ICARDA, Syria \\
\hline 131 & $\begin{array}{l}\text { IG } \\
4244\end{array}$ & P 961 & $\begin{array}{l}\text { USDA,-RPIP, New } \\
\text { Delhi }\end{array}$ & 157 & $\begin{array}{l}\text { ILL } \\
10826\end{array}$ & $\begin{array}{l}\text { ILL } 7620 \times \text { ILL } \\
91517\end{array}$ & ICARDA, Syria \\
\hline 132 & $\begin{array}{l}\text { IG } \\
4253\end{array}$ & P 978 & $\begin{array}{l}\text { USDA,-RPIP, New } \\
\text { Delhi }\end{array}$ & 158 & $\begin{array}{l}\text { ILL } \\
10973\end{array}$ & $\begin{array}{l}\mathrm{ILL} 6024 \times \mathrm{ILL} \\
6829\end{array}$ & ICARDA, Syria \\
\hline 133 & $\begin{array}{l}\text { IG } \\
4281\end{array}$ & P 1044 & $\begin{array}{l}\text { USDA,-RPIP, New } \\
\text { Delhi }\end{array}$ & 159 & $\begin{array}{l}\text { ILL-76 } \\
63\end{array}$ & $\begin{array}{l}\text { Cross between } \\
\text { two locals }\end{array}$ & ICARDA, Syria \\
\hline 134 & $\begin{array}{l}\text { IG } \\
4286\end{array}$ & P 1057 & $\begin{array}{l}\text { USDA,-RPIP, New } \\
\text { Delhi }\end{array}$ & 160 & $\begin{array}{l}\text { EC-542 } \\
161\end{array}$ & Unknown & $\begin{array}{l}\text { NBPGR, } \\
\text { Delhi }\end{array}$ \\
\hline
\end{tabular}

\section{Delhi $\quad 5.2$ Field experiments}

136 IG P $1109 \quad$ USDA,-RPIP, New

\section{Delhi}

Field experiments involving a set of 334 and 160 accessions were conducted on 15 January 2011-12 and 2012-13, respectively at Main Research Farm of Indian Institute of Pulses Research, Kanpur (268270N, 808140E; $152.4 \mathrm{~m}$ above sea level). These experimental materials were evaluated both years in augmented design. Planting of these accessions was delayed 60-70 days from normal planting of lentil during the winter season in order to synchronize high temperature at reproductive stage. Planting was done on ridges and the plot size was a single row of $3 \mathrm{~m}$ length with $30 \mathrm{~cm}$ spacing between rows and $5 \mathrm{~cm}$ between plants within the rows. To avoid possible drought effects, sufficient moisture in soil was maintained by applying regular irrigation. Other standard agronomic practices were also followed in order to raise a good crop.

\subsection{Meteorological data}

Data was collected weekly on temperatures $\left[\left({ }^{\circ} \mathrm{C}\right)\right.$, maximum and minimum] and precipitation ( $\mathrm{mm}$ ) during the growth period of crop from the 


\section{Legume Genomics and Genetics 2016, Vol.7, No.1, 1-11}

BioPublisher http://lgg.biopublisher.ca

agrometeorological observatory of the Indian Institute Pulses, Research, Kanpur.

\subsection{Data recording}

Delayed sowing exposed plants to higher temperature at reproductive phase under irrigated conditions in field. Ten plants were selected randomly from each single row plot in order to take observation on individual plant. Observations were recorded visually on formation of flowers and quantitatively on filled and unfilled pods per plant. Moreover the top 7-8 cm terminal branch of each individual plant was quantitatively recorded for number of filled and unfilled pods under high temperature $\left(>35^{\circ} \mathrm{C}\right)$. The post-harvest data was recorded on 100-seed weight (g) for each genotype. Based on these traits, present germplasm accessions were characterized into (i) sensitive (i.e. plants with flowers but no or rare pods), (ii) highly sensitive (i.e. plants with no or rare flowers and pods), (iii) tolerant (i.e. plants with filled pods but rare/no pods on terminal branch) and (iv) highly tolerant (i.e. individual plans and terminal branch with normal podding) categories (Figure 4).

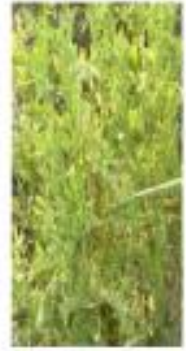

a

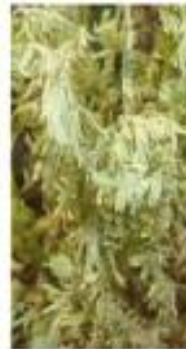

b

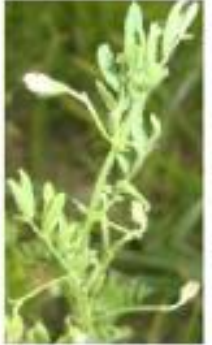

c

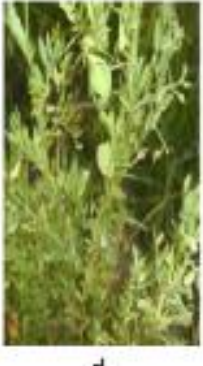

d
Figure 4 Sensitivity of lentil plants during reproductive period under the high temperature (a) sensitive, (b) highly sensitive, (c) tolerant and (d) highly tolerant

\subsection{Determination of pollen viability}

Pollen viability of the fresh pollens was studied in those accessions which showed tolerance on the basis of morphological characters. It was determined by acetocarmine technique (Robert, 1977) and those pollen grains stained deeply and looking normal were counted as viable and weakly stained were counted as non-viable (Pearsonand Harney, 1984). For each genotype, 2000 pollen grains were recorded by counting 200 pollen grains per slide. The pollen viability (\%) was calculated using the following formula.
Pollen viability $(\%)=($ Number of stained pollen $/$ Total number pollen counted) $\times 100$

\subsection{Statistical analysis}

Analyses of variance (ANOVA) were carried out for year-wise data on various traits using the statistical analysis tool of GENSTAT 14th edition (Payne et al., 2011). A combined analysis of variation over years was carried out for partitioning the phenotypic variance into year, genotype, and error variances. Phenotypic correlations were calculated using the mean values over years (SAS Institute, 2007). The critical difference $(\mathrm{CD})$ at $5 \%$ significance level was calculated by using following formula.

$\mathrm{CD}=\sqrt{2} \mathrm{MSe} / \mathrm{no}$. of years $\times \mathrm{t}_{5 \%}$ for error degree of freedom

Where, MSe is the error means of square.

\section{Acknowledgement}

Thanks are due to DAC, Government of India, New Delhi and to CGIAR program on Grain legumes for providing financial support to carry out this study.

\section{References}

Allard R.W., 1960, Principal of plant breeding. John Wiley and Sons, Inc, New York

Devasirvatham V., Gaur P.M., Mallikarjuna N., Tokachichu R.N., Trethowan R.M. and Tan D.K.Y., 2012, Effect of high temperature on the reproductive development of chickpea genotypes under controlled environments. Functional Plant Biololgy, 39: 1009-1018 http://dx.doi.org/10.1071/FP12033

Djanaguiraman M., Prasad P.V.V., Boyle D.L. and Schapaugh W.T., 2013, Soybean pollen anatomy, viability and pod set under high temperature stress, Journal of Agronomy and Crop Science, 199: 171-177 http://dx.doi.org/10.1111/jac.12005

Dua R.P., 2001, Genotypic variations for low and high temperature tolerance in gram (Cicer arietinum), Indian Journal of Agricultural Sciences, 71: 561-566

Erskine W., Sarker A., and Kumar S., 2011, Crops that feed the world 3. Investing in lentil improvement toward a food secure world, Food Security, 3: 127-139 http://dx.doi.org/10.1007/s12571-011-0124-5

Gopesh C.S., Sarker A., Chen W., Vandemark G.J., and Muehlbauer F.J., 2013, Inheritance and linkage map positions of genes conferring agromorphological traits in Lens culinaris Medik, International Journal of Agronomy Volume 2013, Article ID 618926: 9 pages

Gross Y. and Kigel J., 1994, Differential sensitivity to high temperature ofstages in the reproductive development in common bean (Phaseolus vulgaris $\mathrm{L}$.), Field Crops Research, 36: 201-212 http://dx.doi.org/10.1016/0378-4290(94)90112-0

Kalra N., Chakraborty D., Sharma A., Rai H.K., Jolly M., Cher S., Ramesh K.P., Bhadraray S., Barman D., Mittal R.B., Lal M., and Sehgal M., 


\section{Legume Genomics and Genetics 2016, Vol.7, No.1, 1-11}

2008, Effect of increasing temperature on yield of some winter crops in northwest India, Current Science, 94: 82-88

Krishnamurthy L., Gaur P.M., Basu P.S., Chaturvedi S.K., Tripathi S., Vadez V., Rathore A., Varshney R.K., and Gowda C.L.L., 2011, Large genetic variation for heat tolerance in the reference collection of chickpea (Cicerarietinum L.) germplasm, Plant Genetic Resources: Characterization and Utilization, 9(1): 59-69 http://dx.doi.org/10.1017/S1479262110000407

Kumar S., 2006, Climate change and crop breeding objectives in the twenty first century. Current Science, 90: 1053-1054

Kumar S., and M. Ali, 2006, GE interaction and its breeding implications in pulses, The Botanica, 56: 31-36

Lucas M.R., Ehlers J.D., Huynh B.L., Diop N.N., Roberts P.A., and Close T.J., 2012, Markers for breeding heat-tolerant cowpea, Molecular Breeding, 3: 529-536

Payne R.W., Murray D.A., Harding S.A., Baird D.B., and Soutar D.M., 2011, An introduction to GENSTAT for Windows, 14th edn. VSN International: Hemel Hempstead, UK

Pearson H. M., and Harney P.M., 1984, Pollen viability in Rosa, Horticulture Science, 19: 710-711

Ploeg Van der A., and Heuvelink E., 2005, Influence of sub-optimal temperature on tomato growth and yield: A review, Journal of Horticultural Science and Biotechology, 80: 652-659

Porch T.G., and Jahn M., 2001, Effects of high-temperature stress on microsporogenesis in heat-sensitive and heat-tolerant genotypes of Phaseolus vulgaris, Plant Cell Environ, 24: 723-731 http://dx.doi.org/10.1046/j.1365-3040.2001.00716.x

Prasad P.V., Craufurd, and Summerfield R.J., 1999, Fruit number in relation to pollen production and viability in groundnut exposed to short episodes of heat stress, Annals of Botany, 84: 381-386 http://dx.doi.org/10.1006/anbo.1999.0926

Robert W.C., 1977, Pollen-ovule ratios: A conservative indicator of breeding systems in flowering plants, Evolution, 31: 32-46 http://dx.doi.org/10.2307/2407542

Roberts E. H., Summerfield R.J., Muehlbauer F.J., and Short R.W., 1986, Flowering in lentil (Lens culinaris Medic.): the duration of the photoperiodic inductive phase as a function of accumulated day length above the critical photoperiod, Annals of Botany, 58: 235-248

Saini H.S., Sedgley M., and Aspinall D., 1984, Developmental anatomy in wheat of male sterility induced by heat stress, water deficit or abscissic acid, Australian Journal of Plant Physiology, 11: 243-253 http://dx.doi.org/10.1071/PP9840243

Sarker A., Erskine W., Sharma B., and Tyagi M.C., 1999, Inheritance and linkage relationships of days to flower and morphological loci in lentil (Lens culinaris Medikus subsp. culinaris), Journal of Heredity, 90: 270-275 http://dx.doi.org/10.1093/jhered/90.2.270

SAS Institute, 2007, Version 9.1.3 Users guide. Release SAS Institute Inc., Cary, NC, USA

Siddique K.H.M., Loss S.P., Regan K.L., and Jettner R.L., 1999, Adaptation and seed yield of cool season grain legumes in Mediterranean environments of south-western Australia, Australian Journal of Agricultural Research, 50: 375-387 http://dx.doi.org/10.1071/A98096

Subbarao G.V., Kumar Rao J.V.D.K., Kumar J., Johansen C., Deb U.K., Ahmed I., Krishna Rao M.V., Venkataratnam L., Hebbar K.R., Sai M.V.S.R., and Harris D., 2001, Spatial distribution and quantification of rice-fallows in South Asia-potential for legumes, ICRISAT, Patancheru, India

Summerfield R.J., Roberts E.H., Erskine W., and Ellis R.H., 1985, Effects of temperature and photoperiod on flowering in lentils (Lens culinaris Medic.), Annals of Botany, 56:659-671

Wahid A., Gelani S., Ashraf M., and Foolad M.R., 2007, Heat tolerance in plants: an overview, Environmental and Experimental Botany, 61: 199-223 http://dx.doi.org/10.1016/i.envexpbot.2007.05.011 